\title{
English Exit Test: An analysis of the test-takers' performance in the speaking component
}

\author{
Suzana Ab. Rahim, Boon Yih Mah, Zarina Suriya Ramlann
}

\begin{abstract}
The workplace-readiness of the Malaysian graduates is unarguably an issue that the local employers and the Higher Education Providers (HEPs) have a consensus upon. It has been reported by the Malaysian Employers' Federation that more often than not the disability or handicap lies in the poor communicative ability of the graduates who failed to impress their future employers despite their sterling academic performance. One of the hiring criteria for the future employers is that these graduates must be trained to be more verbally competent and eloquent. Hence, this study attempts to conduct a performance analysis of a group of local undergraduates in their English Exit Test (EET) that is made up of written and spoken assessments for them to be workplace-compliant. However, the result has indicated that the test-takers tend to be inhibited when it comes to expressing themselves verbally, which has resulted in a dismal performance in the speaking component. As such, it is a cause for concern to rectify the situation and figure out the solutions to tackle their weak performance. This study also analyses the different performance between the Engineering as opposed to the Hotel Management and Tourism undergraduates, in which a slight difference in their achievement of grades was found. The five dissimilar disciplines of speaking tasks also recorded a difference in their score means achieved by the test takers, which could suggest that treatments are in need to be tailored for those weak performers
\end{abstract} performance analysis, speaking task.

\section{INTRODUCTION}

There are many issues surrounding the fresh graduates' language proficiency particularly when it concerns their ability to secure a job. Reasons to these include their lack of communication skills and poor English proficiency. Next would be the existing mismatches between expectations of Industry and prospective employers and the Higher Education Providers (HEPs). In addition, sadly their chances of being employed are hindered when most of them who are considered very technically sound still require a certain set of soft skills to complement their hard skills.

This brings us to the issue of workplace readiness whereby there is a necessity to nip the problem in the bud after accessing this situation. More importantly, the HEPs and industries must work hand in hand and mutually provide and accept the future workforce that is hoped to be fine-

Revised Manuscript Received on April 19, 2019.

Suzana Ab. Rahim, Academy Of Language Studies, Universiti Teknologi MARA Pulau Pinang, Bukit Mertajam, West Malaysia.(email: suzana.arahim@uitm.edu.my)

Mah Boon Yih,. Academy Of Language Studies, Universiti Teknologi MARA Pulau Pinang, Bukit Mertajam, West Malaysia. (email: mahboonyih@gmail.com)

Zarina Suriya Ramlan, Academy Of Language Studies, Universiti Teknologi MARA Shah Alam, Selangor, West Malaysia. (email: zarinas399@gmail.com)
Keywords: workplace-readiness, English Exit Test,

tuned and moulded according to the benchmarks and expectations of the industries and employers.

As the call for graduates who are globally and locally competent is made, it is only relevant to pinpoint the organization which holds the key and blueprint ascertaining the aims of the HEPs in producing employable graduates. It is the aim of the Ministry of Education (MOE) to produce graduates who are able to "cope in the international job market using English whenever necessary, both at home and abroad" (Zuraidah Don, 2016). MOE in its lauded effort has taken the initiative to align the English education and proficiency levels to the more globally accepted Common European Framework of Reference for Languages (CEFR).

MOE has outlined the CEFR exit target for university students to have a score of $\mathrm{B} 1 / \mathrm{C} 2$ whereby it hopes to be able to establish the proficiency levels at all levels in the education system. University Entry point level is at a Low B2 whereas the exit point is at B2/ C1 (Zuraidah Don, 2016). It is hoped that with the English language Education provided during the tertiary education, students will gain the levels of B2 which will provide students with the skills to independently live and work in an English-speaking country or pursue courses taught in English. As for the C1 holders, this will give them a chance to possess the language skills and proficiency that perspective employers and universities are looking for.

\section{Problem Statement}

Malaysian university undergraduates, despite being exposed to English language education from primary to tertiary level have still shown no distinct improvement.

According to Prof Hazita Azman, some of the probable reasons are the limited hours in formal encounters, language use and being restricted to only fundamental linguistic knowledge apart from it being a foreign language to some (Zulita Mustafa, 2018).

Graduate Employability Blueprint- KPM (Ministry of Education Malaysia Higher Education (MOHE), 2018) summarized that the poor command in English contributed as high as $55.8 \%$ as the main problem reported by Malaysian Employers' Federation (MEF). This has also appeared to be the main problem faced by the employers in getting fresh graduates to be hired (JobStreet, 2018). While Communication skills tops the list of 5 most sought after attributes by Malaysian firms, similarly it is also one of the top five most difficult attributes to be found in the talent pool (Ministry of Education Malaysia Higher Education
Blue Eyes Intelligence Engineering

\& Sciences Publication 
(MOHE), 2012). In fact, as stated by the MEF, some of the employers' predicaments also incude having local graduates who are highly qualified but poor in English. Apart from this, is the issue of these fresh graduates not fulfilling the needs of the industry. Moreover, the World bank (2009) reported the shortages of both cognitive and non-cognitive skills inclusive of the English Language and Communication at $47 \%$ and $36 \%$ respectively contributing to further hiring problems faced by the employers (Ministry of Education Malaysia Higher Education (MOHE), 2012). In fact in the same blueprint for graduates' employability MOHE 2012-2017, 55.8\% of the companies that responded to the survey have concluded that poor command of the English Language is the main factor to why these fresh graduates have difficulty in securing a job and another $30.2 \%$ of the respondent-companies stated the mismatched skills as another contributing factor (Ministry of Education Malaysia Higher Education (MOHE), 2012).

Moreover, in a survey carried out by the Talent Corp in corporation with the World Bank (2014) " $81 \%$ of respondents identified communication skills as the major deficit, followed by creative/critical thinking (56\%), analytical $(51 \%)$ and problem-solving competencies (49\%)" (mystarjob.com, 2014). They are of the opinion that graduates from Malaysian universities seem to be lacking in these aforementioned areas. .

According to a report from Malaysian Employers Federation in Malaysia alone, 200,000 graduates were unemployed due to their poor command of English cited as the main reason. More exasperatingly, 200,000 students graduate from universities annually with a degree but about a quarter end up unemployed annually (Rebecca Rajaendram, 2016).

\section{Research Objectives}

The research objectives are set as following:

i) To determine if there is any significant difference between the Engineering and Hotel test-takers' speaking performance.

ii) To determine if there is any difference between the Engineering and Hotel test-takers' performances among the five speaking tasks.

\section{Research Questions}

1. Is there any significant difference between the Engineering and Hotel test-takers' speaking performance?

2. Is there any significant difference between the Engineering and Hotel test-takers' performances among the five speaking tasks?

\section{Significance of the Research}

This study hopes to provide input to rectify the dismal performance among the undergraduates where speaking is concerned and find out which speaking tasks need more emphasis and exposure to tackle their weak performance. The main concern of this paper is to identify the strengths and weaknesses between the Engineering and Hotel programmes test-takers since there is still room for them to improve and enhance what they are lacking of.

\section{LITERATURE REVIEW}

Oral communication is very pertinent in the challenging workforce and organizations The failure to express oneself with clarity will only result in misunderstandings and miscommunications. It is inevitable that the future graduates equip themselves with effective speaking skills as such skills have their own importance in the organisational processes. There are many instances of communicative tasks that a future employee would have to equip himself with. These productive tasks and activities can easily include addressing the audience giving out information or instructions, speeches from a written text or visual aids (diagrams, pictures, charts etc.), acting out a rehearsed role and speaking spontaneously (Council of Europe, 2001). In addition to that, the language user in an employee is expected to have a range of interactive activities namely conducting transactions, holding casual conversations, informal and formal discussions, participating in an interview or being interviewed, having a negotiation, coplanning and discussing practical goal-oriented cooperation i.e organising a certain event (Council of Europe, 2001).

While it is undeniable that written communication skills are also held highly important, a good command of the language has always been the top-most choice of the prospective employers. A high proficiency in the language has put the candidates at a more advantageous position much as reported in the survey done amongst the employers. The employability skills complemented by hard-skills or technical knowledge and competence dictate that the employees who possess both will not have their chances of being employed impeded. While the expectations of the employers of the employees include having technical and discipline competences, they would also require such graduates to illustrate or display a wider range of skills and characteristics namely communication, critical thinking, team-working, leadership, problem solving as well as managerial skills (Lowden, Hall, Dely, Lewin,\& Elliot, 2011).

Nonetheless, these hard skills will not be put to good use if the graduates have the disability to express themselves well enough orally. Their potentials will not be optimised if their poor communication skills prove to be a hindrance. The fast changing pace and trend in the global world has also outlined that communication skills hold one of the topmost positions for the employability criteria to contend upon and that a university degree is no longer a guarantee of communication skills or technical competence. In fact, another survey by Jobstreet.com recorded the two out of the top 5 reasons for fresh graduate unemployment being their poor command of the English language (52\%) and poor communication skills (49\%) (JobStreet, 2018).

It is evident that with such demands made in the job market, it is pertinent that a drastic move be made for the graduates produced by the HEPs to remain relevant.

When such expectations of the industries and prospective employers are not matched with the output and products of the HEPs, it would result in the graduates failing to secure 
any jobs despite the arduous task of completing their first degree or masters for that matter.

Workplace competencies as expectations of the prospective employers and the reality of graduates today have been confirmed in many studies in the local context of our country (Shahrul Ridzuan Arshad \& Ima Shanaz Wahidin, 2013; Rafikul Islam, Mohd Shukri Abdul Hamid, \& Noor Hazilah Abd Manaf, 2013; Hafizoah Kassim \& Ali, 2010; Latisha Asmaak Shafie \& Surina Nayan, 2010; Rosli Talif and Rohimmi Noor, 2009). According to Wahiza Wahi (2014), in determining the undergraduates' competencies with workplace requirements, there are quite a number of steps to be up-taken to rectify the lacks and the needs of the undergraduates in preparing them for the workforce.

Spurred on by the mismatches of the HEPs and employers' employability criteria, Academy of Language test aligned to CEFR to uncover the oral and written workplace communication competencies. In bridging this gap the university hopes to produce more graduates who are workplace-compliant and thus be more marketable. While it is not easy to provide such communication training and instil the expected attributes and skills, the undergraduates in UiTM have undergone the Exit test and they are given a certificate rating their oral and written proficiency for the employers' choice to ponder upon.

\section{A. English Exit Test (EET)}

The English Exit Test conducted in UiTM is meant for graduating students. Usually it would be taken by students in their last year of studies. Comprising the oral and written tests, students are given the schedule for the test at the beginning of the semester so as to give them some notifications for their preparation for the tests. Similar to this, other universities have also taken the initiative to conduct a competence-based test (Stapa, 2016; Suzana Ab. Rahim, Mah \& Zarina Suriya Ramlan, 2017; Attan et al., 2018).

The Universiti Teknologi MARA English Exit Test for graduating students was first implemented beginning March intake 2015 after the senate approval (Hal Ehwal Akademik UiTM Shah Alam, 2016). With the purpose to measure the university graduates' ability to communicate in English for their workplace readiness, the test aims amongst others to provide the employers with a better insight on the suitability of a candidate. The respective Higher Education provider (HEP) also has aligned its evaluation to the Ministry of Education's CEFR target in which the university hopes to fulfill the aims set by the MOE exit targets as mentioned above.

Furthermore, with the presence of EET, the HEP hopes that it will serve as a target to stimulate and motivate the undergraduates to improve their communication skills in English.

The EET is based on the Common European Framework of Reference for Languages (CEFR) which is used by international \& standardised tests e.g IELTS \& TOEFL.

The levels for the EET are based on CEFR: C2, C1, B2, $\mathrm{B} 1, \mathrm{~A} 2, \mathrm{~A} 1$. The highest level is C2 (Proficient User) while the lowest level is A1 (Basic user). Studies, Universiti Teknologi MARA has resorted to an exit

Since EET is conducted to assess the speaking readiness of the undergraduates for the workplace given different tasks in different contexts, this will lend credence to the students' ability or proficiency to use English upon graduation especially in becoming workplace-compliant. The test-takers are tested in the context of a Semi-formal and formal workplace situations. There is also no pass or fail grade in EET for the candidates as the certificate only bears the respective grade awarded to them.

\section{Speaking component}

The Speaking component of the EET consists of three questions which take up a span of 20 minutes to answer (Ainul Rusmin Ghazali, Asiah Haji Jamil, Chai Moo Hung, Faridah Jaafar, Hamidah Abd Kadir, Kiranjeet Kaur Dhillon, Masturah Alias, Megawati Omar, Nor Shidrah Mat Daud, Noraida Kassim, Raihan Musa, Suchitra Nair, Saidatul Akmar Zainal Abidin, Suhaila Sulong, Zarina Suriya Ramlan, 2016). Held in a computer lab, students are to sit in front of a desktop and equipped with a pair of headphone and microphone ready for them to answer the oral test. The rating scale is based on the CEFR rating scale in which there are 6 bands altogether. The first and the lowest band is A1 and followed by A2. These two bands would indicate that the test-takers are basic users. In addition, there are also two more bands which marked the test-takers as Independent users for a range of band from B2 to $\mathrm{B} 1$. The second highest band would be that of Band $\mathrm{C} 1$ and followed by the topmost $\mathrm{C} 1$ indicating that one is a Proficient user.

\section{5 speaking tasks}

The first question centres on small talks or rather a simulated conversation whereby the test-takers are asked to introduce oneself, relate his or her personal interest and many others. The second part is a job interview whereby this question has three subsections of a, b and c. Question 2a and $2 \mathrm{~b}$ centre on describing oneself, stating some strengths or weaknesses or even, interests. Meanwhile, question $2 \mathrm{c}$ is more of a behavioural question requiring the test-takers to describe their past behaviour or their reaction to a probable situation that they might chance upon during their career. Question 3 requires the test-takers to give an oral presentation based on the stimulus provided on the screen monitor. This stimulus can be in the form of a chart, graph or diagram (Ainul Rusmin Ghazali, Asiah Haji Jamil, Chai Moo Hung, Faridah Jaafar, Hamidah Abd Kadir, Kiranjeet Kaur Dhillon, Masturah Alias, Megawati Omar, Nor Shidrah Mat Daud, Noraida Kassim, Raihan Musa, Suchitra Nair, Saidatul Akmar Zainal Abidin, Suhaila Sulong \& Zarina Suriya Ramlan, 2016). These timed tasks are set in such a way to gauge the test-takers' oral competence and language proficiency as they are required to promptly answer and record their replies within the allotted time.

Past studies on speaking performance and barriers among Malaysian undergraduates especially involving UiTM students. 
There are not so many studies conducted on UiTM students' oral proficiency to date. Many previous studies centered on reading and writing skills and how these skills can be enhanced via various means (Mah, Irfan Naufal Umar, \& Chow, 2013; Chittra Muthusamy, Faizah Mohamad, Siti Norliana Ghazali, 2010; Nor Aslah Adzmi, Samsiah Bidin, Syazliyati Ibrahim \& Kamaruzaman Jusoff, 2009). Another study which also looks at the needs of the undergraduates' language proficiency was conducted on the UiTM Penang Tourism students who were doing their frontdesk internship then (Suzana Ab Rahim \& Farina Tazijan, 2011).

Rusreena Rusli, Melor Md Yunus, \& Harwati Hashim, (2018) investigated on the factors contributing to low English speaking proficiency among the undergraduates and provided possible solutions in students' perspectives to solve their predicament. (Suzana Ab Rahim, 2005) investigated the verbal and written competence amongst engineering undergraduates in UiTM Penang whereby it highlighted the needs and the lacks of the engineering community of the lecturers who had served in the industry and the undergraduates.

Previous studies amongst selected undergraduates investigated their reading and learning styles (Rosniah Mustaffa, 2006) which could promote better learning and another study which looked at the presence of language anxiety amongst language learners in higher education as one of the obstacles faced by them (Noor Hashima Abd Aziz, 2007).

These are only some out of the many studies conducted on Malaysian undergraduates and their language proficiency, competence, needs and lacks. However, the concern of this study is to highlight the undergraduates' performance in relation to their verbal or oral language competence in preparing them for their workplace readiness.

\section{METHODOLOGY}

The study adopted a quantitative approach to data collection and analysis. This study is a comparative study between two consecutive semesters of 2017/4 and 2018/2 English Exit test-takers A group of engineering undergraduates comprising several faculties of engineering namely Electrical, Chemical, Civil and Mechanical were selected apart from a group from the Hotel Management and Tourism faculty. However, the engineering students from these faculties were grouped up and named under "Engineering" since this study focuses on the comparison between the two disciplines and not in any particular engineering faculty.

The 2017/4 batch was a group of 280 final year Engineering and Hotel Management and Tourism students of the same ethnic backgrounds. Meanwhile, the 2018/2 batch was made up of 220 test-takers also from the respective faculties similar to the earlier batch..

The data collection procedure comprises two stages. In the first stage, the test of speaking was administered to the sample of the final year undergraduates. Next, all the audios were graded by the eight trained Exit test examiners, using the speaking rating scales based on the CEFR speaking scales. 10 samples were selected, and graded by the examiners as normed audios. These selected ones were representations of the different levels whereby Level $\mathrm{C} 1$ and C2 Proficient User, Level B1 and B2 Independent User, Level A1 and A2 Basic User of the audio. The ten selected audios were again reviewed by the panel examiners from Shah Alam campus in a workshop together with the eight examiners from the branch campus of Pulau Pinang to ensure that they have mutually agreed on a common score and that there would not be any outliers. After the grading process is completed for almost a month, then only can the analysis be conducted.

This performance analysis was conducted using a descriptive and inferential statistics to compare the achievements of different study programmes and speaking tasks among all the test-takers for both semesters.

\section{A. Participants}

The participants for this study were made up of two semesters i.e 2017/4 and 2018/2. There were altogether 220 and 280 students. For 2017/4 there were 235 Engineering students and 45 Hotel Management and Tourism students whereas for 2018/2, there were 200 Engineering students and 20 Hotel Management and Tourism students.

\section{B. Instruments}

Students' data were gathered via the templates filled in by the examiners submitted to the EET coordinator after the formal results have been announced.

\section{C. $\quad$ Procedures}

Given the research objective is to determine if there is any difference between the Engineering and Hotel management and tourism students, an independent t-test is conducted to seek whether the $p$ value is significant or not. The overall mean scores are also analysed using a t-test to seek the difference in the tasks provided for them.

\section{RESULTS AND FINDINGS}

\section{A. EET test-takers from different programmes}

Table I

Comparison between Hotel and Engineering Test takers for Semester 2017/4

$\begin{array}{lccc}\text { Programme } & \text { N } & \text { Mean } & \begin{array}{c}\text { Std } \\ \text { Deviation }\end{array} \\ \text { Engineering } & 235 & 14.4457 & 3.90067 \\ \text { Hotel } & 45 & 14.6500 & 4.02492 \\ \text { Total } & \mathbf{2 8 0} & & \end{array}$

Table I indicates the mean and standard deviation between the engineering and hotel programmes for semester 2017/4. The hotel test-takers show a slightly higher mean score as compared with the engineering ones. After running the Levene's Test for Equality of Variances, there is no significant difference $(\mathrm{p}>.05)$ in the performance $(\mathrm{p}=$ 0.292 ) between the two groups of test-takers. 
Table II

Comparison between Hotel and Engineering Testtakers for Semester 2018/2

$\begin{array}{lccc}\text { Programme } & \text { N } & \text { Mean } & \begin{array}{c}\text { Std } \\ \text { Deviation }\end{array} \\ \text { Engineering } & 200 & 12.5613 & 3.27321 \\ \text { Hotel } & 20 & 12.2750 & 2.27385 \\ \text { Total } & 220 & & \end{array}$

Similarly, Table II shows the mean and standard deviation between the engineering and hotel programmes for semester 2018/2. As opposed to the previous semester, the hotel test-takers' mean showed a slightly lower mean score than the engineering ones'.

The Levene's Test for Equality of Variances was run on the two means. It is also found that there is no significant difference in the performance between the two groups of test-takers whereby the value $\mathrm{p}=.079$ and thus indicating that $\mathrm{p}>.05$.

\section{B. Table III \\ Comparison between Hotel and Engineering Test- takers for Semester 2017/4 and 2018/2}

\begin{tabular}{lllll} 
Programme & \multicolumn{2}{c}{ Sem 2017/4 } & \multicolumn{2}{c}{ Sem 2018/2 } \\
& N & Mean & N & Mean \\
Engineering & 235 & 14.4457 & 200 & 12.5613 \\
Hotel & 45 & 14.65 & 20 & 12.275 \\
Total & 280 & & 220 &
\end{tabular}

The findings of th e analyses show that the 2018/2 semester results of Table III (mean=12.56 for the engineering and mean $=12.27$ for the hotel students) were not as good as the previous semester of 2017/4 (Table 1) (mean $=14.44$ for the engineering and mean=14.65 for the hotel students).

In summary, the three tables indicate the mean scores between the two programmes which see the higher means occurring in Semester 2017/4 for both programmes. The results did not show any improvement in the overall performance regardless of the slight decline in the mean scores.

\section{EET test-takers from different programmes according to tasks}

Table IV

Comparison between Hotel and Engineering Testtakers for - Semester 2017/4 according to tasks 1 to 3

\begin{tabular}{|c|c|c|c|c|}
\hline Task & Programme & $\mathbf{N}$ & Mean & $\begin{array}{l}\text { Sta. } \\
\text { Deviation }\end{array}$ \\
\hline \multirow{2}{*}{$\begin{array}{l}\text { Task } \\
1\end{array}$} & Engineering & 235 & 2.7670 & .86122 \\
\hline & Hotel & 45 & 2.7111 & .80826 \\
\hline \multirow{2}{*}{$\begin{array}{l}\text { Task } \\
2 a\end{array}$} & Engineering & 235 & 2.8617 & .84164 \\
\hline & Hotel & 45 & 2.9278 & .90551 \\
\hline \multirow{2}{*}{$\begin{array}{l}\text { Task } \\
2 \mathrm{~b}\end{array}$} & Engineering & 235 & 2.9160 & .82923 \\
\hline & Hotel & 45 & 2.9333 & 91453 \\
\hline \multirow{2}{*}{$\begin{array}{l}\text { Task } \\
2 \mathrm{c}\end{array}$} & Engineering & 235 & 2.9638 & 88299 \\
\hline & Hotel & 45 & 3.0667 & .89570 \\
\hline \multirow{2}{*}{$\begin{array}{l}\text { Task } \\
3\end{array}$} & Engineering & 235 & 2.9372 & .84387 \\
\hline & Hotel & 45 & 3.0111 & .80120 \\
\hline
\end{tabular}

\section{Justification of the overall performance}

Table IV highlights the mean for task 1, 2 and 3 according to the programmes as well. Except for task 1, all mean scores for the hotel programme are higher than the engineering programme mean scores. In fact for task $2 \mathrm{c}$ the mean score is the highest in comparison to other tasks for this particular semester.

\section{Table V}

Comparison between Hotel and Engineering Testtakers for - Semester 2018/2 according to tasks 1 to 3

$\begin{array}{lllll}\text { Tasks } & \text { Programme } & \mathbf{N} & \text { Mean } & \begin{array}{l}\text { Std. } \\ \text { Deviation }\end{array} \\ \text { Task } & \text { Engineering } & 200 & 2.4700 & .71530 \\ \mathbf{1} & \text { Hotel } & 20 & 2.3750 & .39320 \\ \text { Task } & \text { Engineering } & 200 & 2.4925 & .66777 \\ \text { 2a } & \text { Hotel } & 20 & 2.5000 & .68825 \\ \text { Task } & \text { Engineering } & 200 & 2.5325 & .70902 \\ \text { 2b } & \text { Hotel } & 20 & 2.5250 & .69727 \\ & & & & \\ \text { Task } & \text { Engineering } & 200 & 2.5463 & .72426 \\ \text { 2c } & \text { Hotel } & 20 & 2.5250 & .41279 \\ \text { Task } & \text { Engineering } & 200 & 2.5200 & .84746 \\ \mathbf{3} & \text { Hotel } & 20 & 2.3500 & .48936\end{array}$

Table $\mathrm{V}$ recorded the mean score for both programmes; engineering and hotel based on tasks 1 to 3 . Only task 2 a recorded a slightly higher mean score for the hotel students in comparison to the engineering programme's mean score at a mere difference of 0.01 . The overall means for the engineering are not that high either ranging from 2.47 to 2.54 .

Table VI

Comparison between Hotel and Engineering Testtakers for - Semester 2017/4 and 2018/2 according to tasks 1 to 3

\begin{tabular}{llrlll} 
& \multicolumn{5}{c}{ Mean Score } \\
$\begin{array}{llllll}\text { Semester } \\
\begin{array}{l}\text { Programme/ } \\
\text { tasks }\end{array}\end{array}$ & Engineering & Hotel & Engineering & Hotel \\
Task 1 & 2.767 & 2.7111 & & & 2.711 \\
& & & 2.47 & & \\
Task 2a & 2.8617 & 2.9278 & 2.4925 & 2.5 & \\
Task 2b & 2.916 & 2.9333 & 2.5325 & 2.525 & \\
Task 2c & 2.9638 & 3.0667 & 2.5463 & 2.525 \\
Task 3 & 2.9372 & 3.0111 & 2.52 & 2.35
\end{tabular}

As indicated in Table VI, performance wise, the engineering programme test-takers showed an overall drop in the performance according to the tasks based on the two semesters. The hotel test-takers' performance in task 1 remains the same nonetheless. In terms of all the speaking tasks for the engineering program test-takers of semester 2017/4, all the tasks show similar degree of decline except for task 1 which declines slightly lesser at 0.3 .

As for the hotel programme test-takers, all the tasks seemed to indicate a greater decline except for task 1 for both semesters of 2017/4 and 2018/2. The highest drop is in 
task 3 whereby the hotel test-takers seem to have performed more poorly than the other tasks.

\section{E. Justification to the performance of the tasks}

In short, there was not any noticeable improvement in the mean scores presented in the two semesters' analyses. The tasks assigned are still similar for both semesters and yet the test-takers did not manage to obtain a higher mean score.

\section{CONCLUSION}

The main objective of the study is to investigate the difference in performance between the engineering and hotel programme test-takers.

The findings reveal that the mean scores between the respective programmes do differ and that there are some mean scores that dropped quite noticeably between the programmes as well as the semesters. As for the performance in the tasks that are measured, even with a constant mean score in task 1 , the hotel test-takers did not manage to score a bit higher than the previous semesters for other tasks.

This normal occurrence is to suggest that this could be due to the fact that task 1 is made up of quite basic conversation skills of making a small talk instead of dealing with something they are yet to familiarize themselves with i.e job interview in task 2 .

They also could have done better with a bit more training and exposure to the tasks despite not having any formal classes or input for this course.

Task 3 which requires them to have a good grasp of vocabulary in reporting and presenting a stimulus apart from giving justifications is also a task that is quite challenging to the test-takers.

Finally, there should be some form of technology enabled tools to help these students out since there isn't any formal training for this exit test. After all, the dismal performance especially due to the lack of exposure of training could easily be rectified with the introduction of any digital tools for the fact of being the digital natives as they are.

\section{RECOMMENDATION FOR FURTHER STUDIES}

This study could further look into certain mechanism that can help initiate the interest of the test-takers in wanting to do better in their speaking performance. In relation to their performance, another study could be done to collect feedback from the relevant parties on how these measures are to remain relevant with the prospective employers.

\section{REFERENCES}

1. Ainul Rusmin Ghazali, Asiah Haji Jamil, Chai Moo Hung, Faridah Jaafar, Hamidah Abd Kadir, Kiranjeet Kaur Dhillon, Masturah Alias, Megawati Omar, Nor Shidrah Mat Daud, Noraida Kassim, Raihan Musa, Suchitra Nair, Saidatul Akmar Zainal Abidin, Suhaila Sulong, Z. S. R. (2016). UiTM English Exit test The Official Guide. Academy of Language Studies, Universiti teknologi MARA Shah Alam.

2. Attan, A., Ali, N. L., Habil, H., Stapa, M., Md Saleh, Z., \& Abdul Raof, A. H. (2018). Revisiting the Writing
Competencies Expected by Industries in an Exit Test. LSP International Journal, 5(1), 13-22. https://doi.org/10.11113/lspi.v5n1.61

3. Chittra Muthusamy, Faizah Mohamad, Siti Norliana Ghazali, \& A. S. @ M. (2010). Enhancing ESL writing creativity via a literature based language instruction. Studies in Literature and Language, 1(2), 36-47.

4. Council of Europe. (2001). Common European framework of Reference for Languages: learning, teaching, assessment.

5. Hafizoah Kassim, \& Ali, F. (2010). English communicative events and skills needed at the workplace: Feedback from the industry. English for Specific Purposes 29, 29, 168-182. Retrieved from https://www.sciencedirect.com/science/article/pii/S08894 90609000635

6. Hal Ehwal Akademik UiTM Shah Alam. (2016). UiTM English Exit Test The Official Guide.

7. JobStreet. (2018). JobStreet.com Fresh Graduate Report 2018-Top 5 reasons for fresh graduate unemployment. Retrieved

from https://www.jobstreet.com.my/announcement/FTP/FACT -SHEET_Fresh-Graduate-Survey-2018.pdf

8. Latisha Asmaak Shafie, \& Surina Nayan. (2010). Employability Awareness among Malaysian Undergraduates. International Journal of Business and Management, 5(8). Retrieved from http://www.ccsenet.org/journal/index.php/ijbm/article/vie w/6917

9. Lowden, K., Hall, S., Dely, E., Lewin, J., Elliot, D. (2011). Intelligence in the flesh Employers' perceptions of the employability skills of new graduates. https://doi.org/https://doi.org/ISBN 978-0-9565604-3-8

10. Mah, B. Y., Irfan Naufal Umar, \& Chow, V. F. T. (2013). L2 writing challenges for the undergraduates: a performance analysis and a literature review on SIL domains. $\quad$ Retrieved from http://iafor.org/archives/offprints/acll2013offprints/ACLL2013_0162.pdf

11. Ministry of Education Malaysia Higher Education (MOHE). (2012). National Graduate Employability Blueprint 2012-2017.

12. mystarjob.com. (2014). Matching talents to jobs. Retrieved from https://www.talentcorp.com.my/clients/TalentCorp_2016 _7A6571AE-D9D0-4175-B35D99EC514F2D24/contentms/img/publication/MatchingTalent-to-Job-1.pdf

13. Noor Hashima Abd Aziz. (2007). ESL Students Perspectives on Language Anxiety. Retrieved from https://www.researchgate.net/publication/277984526_ES L_Students'_Perspectives_on_Language_Anxiety/downl oad

14. Nor Aslah Adzmi; Samsiah Bidin; Syazliyati Ibrahim; Kamaruzaman Jusoff. (2009). The Academic English Language Needs of Industrial Design Students in UiTM Kedah, Malaysia. Retrieved March 29, 2016, from https://files.eric.ed.gov/fulltext/EJ1083732.pdf

15. Rafikul Islam, Mohd Shukri Abdul Hamid, \& Noor Hazilah Abd Manaf. (2013). Enhancing Graduates ' Employability Skills: A Malaysian Case. Enhancing Graduates'employability Skills: A Malaysian Case. In: Academy of International Business (MENA): Third Annual Conference 2013, 12-14 January, 2013, Cairo, 
Egypt., 1-17.

16. Rebecca Rajaendram. (2016). English skills vital for all. Sunday, 12 June 2016. Retrieved from https://www.thestar.com.my/news/education/2016/06/12/ english-skills-vital-for-all/

17. Rosli Talif and Rohimmi Noor. (2009). Connecting Language Needs in the Workplace to the Learning of English at Tertiary Level. Pertanika J. Soc. Sci. \& Hum. 17 (2): 65 - 77 (2009), 17(2), 65-77.

18. Rosniah Mustaffa. (2006). The effects of culture on students' learning styles. 3L The Southeast Asian Journal of English Language Studies, 12, 83-94.

19. Rusreena Rusli, Melor Md Yunus, \& Harwati Hashim. (2018). Low Speaking Proficiency Among the Malaysian Undergraduates: Why and How? E-Prosiding Persidangan Antarabangsa Sains Sosial Dan Kemanusiaan 2018, (April), 678-689.

20. Shahrul Ridzuan Arshad, \& Ima Shanaz Wahidin. (2013). The Development Of Malaysian Online Employability Test Kit (MASKIT): A Prototype For Language Component. WCIK E-JOURNAL OF INTEGRATION KNOWLEDGE 2013. Retrieved from http://worldconferences.net

21. Stapa, S. H. (2016). Development of competence based English Test for workplace readiness (pp. 14-21). Retrieved from http://ejournal.unp.ac.id/index.php/selt/article/view/6904

22. Suzana Ab. Rahim, Mah, B.Y., \& Zarina Suriya Ramlan. (2017). English Exit Test (EET) And Competence-Based English Test (CBET) As Verbal Competence Measures For Employability: A Comparative Systematic Review. International Academic Research Journal of Social Science, 3(1), 135-141. Retrieved from http://www.iarjournal.com/wpcontent/uploads/IARJSS2017_1_135-141.pdf

23. Suzana Ab Rahim. (2005). A needs analysis of communication skills required by engineering undergraduates in UiTM Penang. Universiti Sains Malaysia.

24. Suzana Ab Rahim, \& Farina Tazijan. (2011). Analyzing the Training and Internship Needs Assessment of Verbal Communication Skills amongst Hotel Practitioners. English Language Teaching, 4(3), 44-53. https://doi.org/10.5539/elt.v4n3p44

25. Wahiza Wahi. (2014). English Language Literacy: Juxtaposing Undergraduate Students " Competencies with Workplace Requirements. International Journal of Language Education and Applied Linguistics (IJLEAL), (ISSN: 2289-7208. 01.), 19-31.

26. Zulita Mustafa. (2018, July). Proficient way to better English. Retrieved from http://www2.nst.com.my/education/2018/07/389562/prof icient-way-better-english

27. Zuraidah Don. (2016). CEFR Familiarisation TrainingTertiary [Powerpoint Slides].

\section{AUTHORS PROFILE}

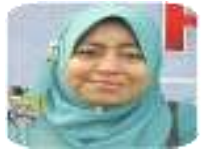

First Author Suzana Ab. Rahim is a senio lecturer at Academy of Language Studies, UiTM (Penang). She holds a Master degree in Applied Linguistics and English Language Studies from Universiti Sains Malaysia. She is currently pursuing her doctoral studies in Applied Language Studies. Her research interests include Web-based Instructional Studies, Language and Communication Skills, English Exit Test and workplace readiness

Second Author Dr Mah Boon Yih is a senior lecturer at Academy of Language Studies, UiTM (Penang). He holds three degrees: PhD (Elearning), MA (Applied Linguistics), and BAEd (Hons) in ELS. He has completed his doctoral study in 2015 at Centre for Instructional Technology and Multimedia, USM after receiving a scholarship from Ministry of Education Malaysia in 2011

Third Author Associate Professor Dr Zarina Suriya Ramlan has been a full-time lecturer in the English Department Academy of Language Studies, UiTM since the 1980s. She has a vast experience in teaching English as a Second Language - from basic to proficient users. For the past 10 years she has been teaching English Professional Communication courses, Linguistics and Research Methods at degree level for the Bachelor of Applied Language Studies program. She also teaches Research Methods at postgraduate level. In 2013, she was in the team that came up with the Diploma in English for Professional Communication and Bachelor of Applied Language Studies (Hons) English for Intercultural Communication. In 2015 she led a team that came up with the English Exit Test for Universiti Teknologi MARA. Dr Zarina Suriya Ramlan earned her Doctorate Degree from the University of Malaya in 2009. She was in Georgetown University,Washington DC, USA for a master program specialization in TESOL and Bilingual Education. She earned her Bachelor of Education (English) in 1984 in Wichita State University, Wichita, Kansas. Her research interests include curriculum, Professional Communication, Linguistics and Research Methods. 